LUIZ COSTA LIMA é professor de

Teoria da Literatura e Literatura Brasileira na UERJ e ensina no Programa de História Social da Cultura da PUC-RJ. É autor da trilogia formada por "O controle do imaginário" (Brasiliense),

"Sociedade e discurso ficcional" (Guanabara) e "O fingidor e 0 censor" (Forense). Seu "Aguarraz do tempo - Estudos sobre a narrativa" sai, pela Rocco, este ano.

\section{Uma questão da modernidade: o lugar do imaginário}

\author{
Luiz Costa Lima
}

\section{Modernidade e racionalidade}

A propósito da modernidade, poucas serão as afirmações tão agudas, precisas e famosas quanto a weberiana: caracteriza a modernidade o desencantamento (Entzauberung) do mundo. Mas que se entende por tal processo? O mundo se desencanta, pensamos numa primeira aproximação, quando valores racionalmente orientados preponderam sobre conjuntos axiológicos em que um papel decisivo é reservado à afetividade. Era n€cte sentido que Ludwig Tieck opunha "os doces tons" com que "pensa o amor" e "o pensamento que se põe à distância" (Liebe denkt in süssen Tönen/ denn Gedanken stehn zur ferne).

Se bem que, grosso modo correta, a postulação acima provoca uma imediata suspeita: como se falaria de uma flecha de razão capaz de secar, marginalizar ou mesmo expulsar a afetividade do campo dos valores sem que, automaticamente, se emprestasse àquela flecha uma conotação negativa? Ora, a posição de Weber quanto à Entzauberung no máximo poderia ser tida como ambígua; nunca como negativa (Para que o fosse, seria necessário que, entre as três formas de dominação nomeadas em Economia e sociedade (1922) - os tıpos racional, tradicional e carismático - 0 autor manifestasse seu enfado pelo primeiro e sua simpatia por um dos restantes). Para superarmos a justa suspeita em que se envolve nossa primeira aproximação, será, pois, preciso desenvolvê-la.

É no próprio Weber que lemos: "A tensão entre a religião e o conhecimento intelectual vem ao primeiro plano onde quer que o conhecimento racional e empírico tenha levado ao desencantamento do mundo e à sua transformação em um mecanismo causal" (Weber, M., 1915, 350).

Desde a dostoievskiana "morte de Deus", já poderíamos saber que a modernidade de algum modo se relaciona com o desprestígio do religioso e daí com um dos condutos de expressão da afetividade. Mas a passagem de Weber não se restringe a corroborar uma percepção; ela nos ensina a articular a morte de Deus com o nascimento de um novo: o conhecimento empíricoracional. Como divindade, também esta postula um primeiro mandamento, no caso chamado princípio da causalidade. Contudo, a articulação indicada não parecerá evidente para o leitor que recorde a continuação da passagem dostoievskiana: estando Deus morto, tudo se torna possivel. Como dar-se-ia essa ampla possibilidade se o novo Deus ordena seu império justamente através da causalidade mecânica? Não podemos, a respeito, esquecer que o corolário do romancista aponta para a área da ação humana, ao passo que a causalidade mecânica implica que as relações no mundo físico são necessárias e determinadas. A causalidade realçada ordena o campo dos objetos, dos Gegen-stände, i.e., do que literalmente se põe diante-de. Quanto à ordem subjetiva e humana, a causalidade mecânica ao menos de imediato se cala. $O$ que vale dizer, calam-se os mandamentos éticos do antigo Deus. Para um mundo causalmente determinado, os princípios éticos ou são redundantes, ou são arbitrários. O "tudo é possivel" dostoievskiano não é pois uma liberalização da conduta, senão que a resultante da abolição do significado que se emprestava à conduta. O primado da razão científica implica, pois, uma restrição do campo do que faz sentido. Dito de modo mais explícito: no interior da Entzauberung, o sentido não se origina de uma decisão 
da vontade senão que é algo que necessariamente se impõe. A causalidade mecânica, ao menos de imediato, se cala perante o subjetivo porque de imediato a física e a matemática não têm nada a dizer sobre ele (Escusado acrescentar: esse seu poder só será atingido quando o determinismo científico se desdobrar sob a forma das ciências humanas e sociais). É correto pois afirmar-se que, em termos weberianos, a afirmação do desencantamento da modernidade supõe que a racionalidade científica recusa sentido a um cosmo "significativa e eticamente orientado".

Antes mesmo que o leitor se aperceba do que visamos com a reflexão weberiana, ainda será preciso que a compreendamos melhor. Com efeito, é provável que das linhas precedentes surja uma nova questão: tal como aparece formulada, a Entzauberung pressupõe que o processo de racionalidade colide com um cosmo religiosamente orientado. Mas em que esse choque se funda? Porventura estaria Weber dizendo que a irracionalidade é o preço pago por termos acesso a um cosmo saturado de significação, a exemplo do religiosamente ordenado? Que o homem-da-razão necessariamente é antagônico ao que é capaz de dar significação aos afetos? Não, Weber não é culpado do simplismo. Sem sairmos do ensaio de 1915, notemos como sua reflexão se desenrolava.

As relações entre racionalismo e visão religiosa do universo não são a priori hostis, mesmo porque "em todos os tempos e em todos os lugares, a necessidade de salvação - conscientemente cultivada como a substância da religiosidade - resultou do esforço em prol de uma racionalização sistemática e prática das realidades da vida" (Weber, M., 1915, 353). Mesmo que nem todas as religiões tenham sido obrigadas ao processo de desantropomorfização e de desmitologização que se impôs ao cristianismo dos primeiros séculos de nossa era (cf. Blumenberg, $\mathrm{H}$., 1979, espec. cap. II), afirma Weber que todas tiveram de oferecer um plano racional que respaldasse a plenitude significativa que concediam ao cosmo. Isso, entretanto, não impedia que a razão religiosa, independente e antes da modernidade, se chocasse com a razão de ordem estritamente econômica. À medida que as relações de fraternidade traziam para a comunidade religiosa a obrigação de ajuda aos pobres, às viúvas e aos desamparados, a imposição de uma ratio, ao contrário econômica, só poderia ser vista com suspeita, senão mesmo com hostilidade. Essa hostilidade se torna mais forte porque tanto o princípio religioso, quanto a razão econômica, operavam com um mesmo critério abstrato e despersonalizante. No caso das religiōes da salvação, tal critério contudo se centrava no amor - "(...) As religiões da salvação tenderam a despersonalizar e a objetivar o amor no sentido único do acosmismo" (Weber, M., op. cit., 331) - ao passo que a ratio econômica não contém parâmetros para os afetos; seu critério de despersonalização centra-se antes em um cálculo quantitativo do que no acosmismo de uma qualidade. Weber ademais anota que o mesmo choque tende a se repetir entre o ethos religioso e as orientaçōes de cunho erótico e artístico. O refinamento erótico supōe uma intelectualização da mera atração física, que perverteria o próprio sentido da fraternidade, pois que provocaria o aumento da coerção do parceiro mais forte sobre o seduzido. "Pretendendo ser a mais humana das devoções, (o erotismo) é o desfrute sofisticado de si mesmo no outro" (idem, 348). Não é menor a tensão potencial com o artístico. A significação religiosamente concedida ao mundo tem como consequêencia a desqualificação da forma, por ser esta demasiado particular e ligada ao mundo. Essa tensão tende a aumentar quando uma visão estética tem condiçōes históricas de ressaltar e propagar a "lógica inerente à arte".

Em suma, para Weber, os impulsos para o erótico, o artístico, o religioso e o econômico são internamente contraditórios porque implicam orientações em última análise antagônicas. Daí deriva que a dominância de uma dessas áreas provoca a restrição acomodadora das outras. Não custa esforço daí perceber-se $o$ intenso trauma que acompanha a passagem de uma para outra forma de dominância. No caso específico da modernidade, esse trauma é amenizado pelo aparecimento do puritanismo - em termos mais amplos, da ética protestante. Para o puritano, o mundo é ao mesmo tempo desvalorizado e confundido com o campo útil para o trabalho de Deus. A rotina econômica é a ferramenta para essa colheita. O puritano aferra-se ao trabalho, não porque de imediato visa ao domírio do mundo, senão porque o ascetismo interno imprescindível ao trabalho favorece a edificação da própria alma. Assim era neutralizada a tensão com a ratio econômico-capitalista. A rotina do homo oeconomicus converte-se em caminho religioso. Deste ponto de vista, pouco importa que tal valorização da atividade individual rompesse com a idéia de fraternidade, que estivera na base do cristianismo. Importa sim que o ethos puritano concilia o desencantamento estimulado pelo avanço dos conhecimentos empírico e científico com a possibilidade de manter-se dentro do marco de uma fé. A prática da fé religiosa se torna possível mesmo em um mundo de que se exila o sentido cósmico. A ética protestante permite que seus praticantes vivam de modo menos traumático a "morte de Deus". Morto no interior da rotina da vida, que rejeita qualquer princípio de fraternidade, Deus permanece vivo enquanto promessa da graça que, aleatoriamente, e sem que nunca ao certo o saibamos, poderá privilegiar este ou aquele. 


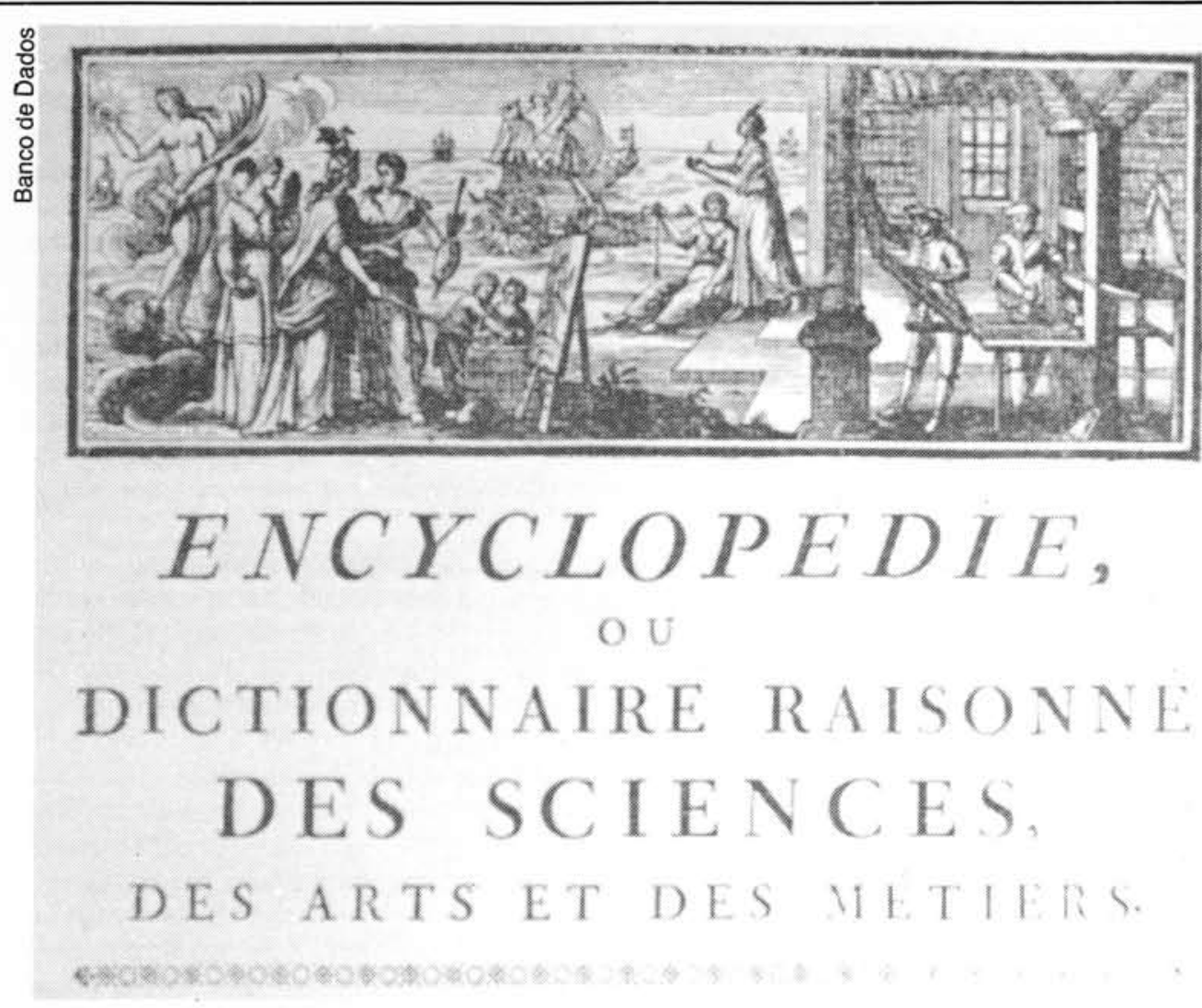

Parte da página de abertura da

"Enciclopédia" editada por Diderot e D'Alembert entre $1751 \mathrm{e}$ 1765

(1) Distinguimos o imaginário da imaginaçáo tomando o primeiro como faculdade e a segunda como sua atua. ção. $\mathrm{O}$ trabalho conceitual, aqui nãoensaiado, há pois de se referir ao primeiro.
As consideraçōes sobre Weber se impuseram para a própria introduçāo de nosso tema. Sinteticamente, elas assinalaram que a Entzauberung caracteristica da modernidade supōe: (a) a reorientação do que faz sentido. Nesta direção, é paradigmática a distinção feita por Kant: Newton nos faz entender como atua a gravitação sem que se preocupe com sua causa originária; (b) através dessa reorientação se efetua o esvaziamento do sentido emprestado ao cosmo, agora restrito aos limites do que a razão pode conhecer; (c) esvaziamento que podemos supor menos traumático desde o advento do ethos protestante.

De passagem, poderíamos sugerir que, no cristianismo como um todo e não só em sua variante protestante, há algo que abrandou o trauma da passagem para a modernidade. Em comentário a breve trecho de Luciano de Samosata, Leonardo Sciascia anota que o escritor da decadência romana compreendia que "os cristāos nāo se preocupam com que a escolha da pobreza, a prática da comunhão dos bens seja rigorosamente provada por todos e cada um; ou seja, testemunhada, vivida" (Sciascia, L., 1974, X). Ou seja, o fato de que já os primeiros cristāos não se preocupassem com que seu princípio de fraternidade fosse rigorosamente testemunhado tanto pode ser interpretado, a exemplo de Sciascia, como il punto debole da nova fé, quanto como o traço que facilitará aos cristãos da modernidade a convivência com as estruturas do mundo desencantado. Mas o argumento é aqui secundário. O decisivo será relacionar a Entzauberung técnica e cientificamente operada com a questão das tensōes com as outras áreas além da religiosa. Mais precisamente: da Entzauberung da modernidade com a faculdade do imaginário( ${ }^{(1)}$. Para esboçá-lo, utilizaremos duas vias. A primeira envolverá um argumento geral e por força abstrato; a segunda, uma demonstração indutiva e particularizada. As duas se impōem na tentativa de se complementarem: se o argumento geral tem a vantagem de permitir o descortino da raiz e da extensão do problema, sem contudo possibilitar sua efetiva análise, o inverso se passa com a segunda via: se o tratamento indutivo de um texto particular tem a desvantagem de ser demasiado restrito, contudo compensa a falta da suficiente concretude do argumento geral. O primeiro argumento será pois apresentado na continuação imediata, enquanto ao item seguinte será reservado o tratamento do segundo.

Tanto em autores ingleses como continentais, o ataque à religião "não-racional" se associava a acusações à força maléfica do imaginário. Assim, para John Trenchard, as práticas do jejum, do açoite e da reclusão eram "meramente recursos mecânicos que induziam a estados psíquicos semelhantes aos gerados pelas doenças do corpo e pelos desarranjos mentais ordinários" (apud Manuel, F., 1959, 76-7). Aqueles que lançavam mão de tais meios eram verdadeira- 
mente enfermos e as alucinações provocadas, o desideratum buscado por sua doença. Embora a palavra "imaginação" não se explicite na descrição de Trenchard da psicopatologia da experiência religiosa, dela está próxima a alucinação a que se refere: uma e outra se originam do bloqueio do comércio que os ógãos dos sentidos mantêm com o mundo externo; uma e outra tornam o homem sujeito a fantasmas. Assim, em texto originalmente publicado em 1724, Fontenelle não hesitava em caracterizar o homem "dos primeiros séculos" como alguém governado por suas próprias fantasias: a imaginação não domina senão onde impera uma razão infantil. Daí a origem das fábulas, pois "à medida que se é mais ignorante e que se tem menos experiência, mais se vêem prodígios" (Fontenelle, Le Bovier de, 1724, 271). Os deuses não nasceram senão pela debilidade da razão humana. Deles não se deveria apenas dizer que são marcados pela força da imaginação, quanto pela linguagem analógica desta:

\begin{abstract}
É bastante curioso ver como a imaginação humana concebeu as falsas Divindades. Os homens vêem bem coisas que não teriam podido fazer: lançar os raios, excitar os ventos, agitar as ondas do mar, tudo isso estava muito acima de seu poder; imaginarari seres mais potentes do que eles e capazes de produzir esses grandes efeitos. Era bem preciso que estes Seres fossem feitos como homens, que outra figura poderiam ter? (idem, 275-6).
\end{abstract}

A imaginação é pois uma força mais primitiva, o que vale dizer, apropriada à ignorância dos primeiros tempos. Dela deriva não só a mentira agradável das fábulas quanto a crença que acompanha a figuração analógica encarnada no panteão politeísta. A imaginação é o primeiro termo de uma cadeia constituída por credulidade (superstição) - fábulas (com pretensão à verdadeira história) - religião "primitiva" ("Da maneira como a imaginação é feita, ela se contenta com pouca coisa \& reconhecerá sempre como uma Divindade o que tiver um pouco mais de poder que um homem") (ibidem, 278). A imaginação é uma capacidade inferior, cujo reino só é contrariado por le goût de vouloir qu'on écrive les faits dans leur exacte vérité (ib., 283). Assim pois o protoevolucionismo do enciclopedista Fontenelle tinha por base a oposição entre imaginação e razão. A imaginação é a sede da mentira das fábulas e dos deuses antropomorfizados. Mas um terceiro efeito ainda se associa à imaginação:

\begin{abstract}
Na maioria dos povos, as fábulas se converteram em religião, porém, mais do que isso, nos gregos, converteram-se, por assim dizer, em agrado. Como elas não fornecem senāo idéias conformes ao giro de imaginação mais usual entre os homens, a poesia e a pintura com elas se acomodaram muito bem e sabe-se que paixão tinham os gregos por estas belas artes (ib., 291).
\end{abstract}

Ao assinalar o terceiro efeito da imaginação, Fontenelle se dá condições de verificar a assimetria entre os efeitos religioso e artístico. Quanto ao primeiro, os contemporâneos poderiam sentir-se aliviados ao se saberem descendentes do "povo eleito", o único preservado pela Providência da atração pelo fabuloso - "(...) Não há nenhum povo cuja história não comece por fábulas, exceto o povo eleito (...)" (ib., 290). Mas a mesma Providência parece não haver sido tão zelosa no que respeita à poesia e à pintura, pelas quais, mesmo em uma idade da razão, a imaginação continua a seduzir: "A religião e o bom senso nos desenganaram (nous ont désabusés) das fábulas dos gregos, mas elas ainda se mantêm entre nós por meio da poesia e da pintura, que parece terem encontrado o segredo de se tornarem necessárias" (ib., 292). Fato que bem parece desagradar o pensador que então lapidarmente acrescenta: "Nada prova melhor que a imaginação e a razão não têm comércio entre si (n'ont guère de commerce ensemble) e que as coisas de que a razão está plenamente desenganada nada perdem de seu agrado, no que toca à imaginação" (ib., 292-3). Há algo pois no homem insubmisso aos ditames da razão. Daí a advertência com que Fontenelle fecha seu ensaio. Contra a admiração dos antigos, é preciso que os contemporâneos compreendam a luta que separa a razão da imaginação e que nas fábulas não busquem senão "a história dos erros do espirito humano". Advertência tanto mais necessária porquanto "todos os homens tanto se assemelham que não há povo cujas tolices não nos devam fazer tremer" (ib., 296).

Por mais curioso que nos pareça o De l'origine des fables, é ainda mais impressionante o documento que nos vem do fim do século anterior. Na Réponse aux questions d'un provincial (postumamente publicado em 1731), Pierre Bayle em sua busca de objetividade "científica" e de, dentro destes parâmetros, combater em prol da conciliação entre razão e fé( ${ }^{(2)}$, analisava as causas da psicopatologia religiosa e descartava a fraude dos padres como seu verdadeiro motivo. Este se depositaria em algo mais entranhadamente humano:
(2) Sobre essa busca obstinada no famoso calvinista recorde-se a observação de Dieckmann: "Ela (a razăo) não é nem pura faculdade subjetiva, nem seus critérios são de origem empirica: ela é como lumen naturale concedido por Deus ao homem e encontra suas linhas de orientaçăo na consonáncia das consciências religiosa e moral" (Dieckmann, H., 1974, 323-4). 
As cabeças mais razoáveis têm sonhos extravagantes e formam quimeras mais bizarras do que os loucos que encerramos nos asilos. Os objetos dos sonhos aparecem como se estivessem presentes aos sentidos externos; crê-se que se vêem faunos e sátiros, que se escuta a árvore falar ou o rio. De onde vem tudo isso? Do fato de que a ação dos sentidos é interrompida e que a imaginaçăo domina. O mesmo pode suceder àqueles que não estão a dormir se, por efeito de algum medo ou de alguma poderosa emoção, os atos da imaginação tiverem poder maior do que os da vista e da audição (apud Manuel, F., 1957, 37).

A imaginação encarna o demônio da inconfiabilidade. Se o testemunho dos sentidos já é inseguro, que dizer quando não se esteja em estado de vigîia? O risco da imaginação é iminente quer no estado onírico, quer sob o estado de grande emoção. Contra ele, na frente externa só há o mundo, na frente interna a capacidade de razão, entre um e outro, a vontade de verdade (entendase, em sentido não-nietzschiano).

Poder-se-ia contudo afirmar que essas provas são unilaterais por derivarem de adeptos de um mesmo racionalismo otimista. Mas que dizer se a mesma associação aparecer em um cético na razão como Hume? Seu ceticismo se afirmava em negar a possibilidade de uma religião mais "evoluída", não em recusar a interligação entre experiência religiosa e uso do imaginário:

A loucura, a fúria, a raiva e uma imaginação inflamada, embora ponha
os homens mais próximos ao nível dos animais, são, (...), com freqüên-
cia tomadas como as únicas disposiçōes pelas quais poderiamos nos
comunicar imediatamente com a divindade (Hume, D., 1757, 42).

O ensaio do filósofo inglês é muito relevante para que o limitemos a uma curta transcrição. À primeira vista, sua argumentação consistiria em provar a correspondência estabelecida entre imaginação, superstição e politeísmo, assim como a inversa entre razão e monoteísmo. $\mathrm{O}$ politeísmo derivaria não da speculative curiosity ou de the pure love of truth senão que das "afeições ordinárias da vida humana". "Agitados pelas esperanças e temores dessa natureza, (...) os homens examinam com temerosa curiosidade o curso das causas futuras e perscrutam os vários e contrários eventos da vida humana. E nesta cena desordenada, com olhos de ainda maior espanto, vêem os primeiros e obscuros traços da divindade" (idem, 28). Aquelas paixões contudo por si ainda não criariam deuses. Para tanto é ainda preciso que "a imaginação" seja "igualmente empregada em formar idéias daqueles poderes". Pois a imaginação atua em dupla direção: por um lado, ajuda a mente a concretizar as figuras não-humanas (divinas), que explicariam as unknown causes que nos angustiam; por outro; processa as poetical figures and expressions. Conquanto essa dupla produção não pertença ao mesmo espaço, i.e., embora a figuração poética não seja necessariamente objeto de crença, porém, sobretudo no homem comum, se observa a tendência de que se superponham. "Nem sempre os deuses das margens (river-god) ou hamadriades são tomados como meros personagens poéticos ou imaginários; algumas vezes podem ingressar na crença real do vulgar ignorante" (ibidem, 29).

Se considerássemos suficiente essa primeira leitura, as posiçōes de Hume, embora mais sofisticadas, no fundo concordariam com o proto-evolucionismo de Fontenelle. Mas Hume se afasta desse acordo por negar ao tempo histórico a função depuradora, pois essa é a condição necessária para que o monoteísmo, enquanto produto de uma razão abstratizante, seja tido por uma crença superior. Para Hume, monoteísmo e politeísmo não são formas de crença necessariamente diversas, i.e., necessariamente associadas a faculdades mentais discrepantes. Por isso é que "os homens têm a tendência natural de erguer a idolatria até o deísmo e de retornar do deísmo à idolatria" (ib., 46-7). Além do mais, o monoteísmo não é uma forma superior de experiência do divino, porque o maior refinamento de sua justificação teológica apenas torna seus crentes mais intolerantes. "A intolerância de quase todas as religiōes que têm professado a unidade de Deus é tão assinalável quanto o princípio contrário dos politeístas" (ib., 50). Essa retificação destrói portanto a possibilidade da primeira leitura. O que significa dizer: em termos de experiência religiosa, o elemento gerador, a imaginação, tanto abrange a superstição politeísta como a prática ou supersticiosa ou intolerante do monoteísmo. Os efeitos do monoteísmo são mesmo mais nocivos porque respaldados por uma razão agora pervertida - seu melhor argumento teológico propicia fa-

(3) É certo que a partir daf se poderia reconsiderar o papel reservado à imaginação, enquanto sua produção das figuras poéticas năo é necesseriamente superponivel à crenças religiosas. Fazê-lo contudo ultra tudo ultrapassaria os limites da presente abordagem. náticos mais absolutos. Contudo, apesar dessa grande mudança, a razão permanece o termo positivo. À diferença do racionalismo otimista, o racionalismo cético de Hume apenas desconecta a razão de um efeito necessário, caracterizador pois de um necessário progresso observável na sociedade humana. A razão, como fundamento da tolerância, é cultivável apenas por indivíduos isolados, os filósofos $(3)$. 

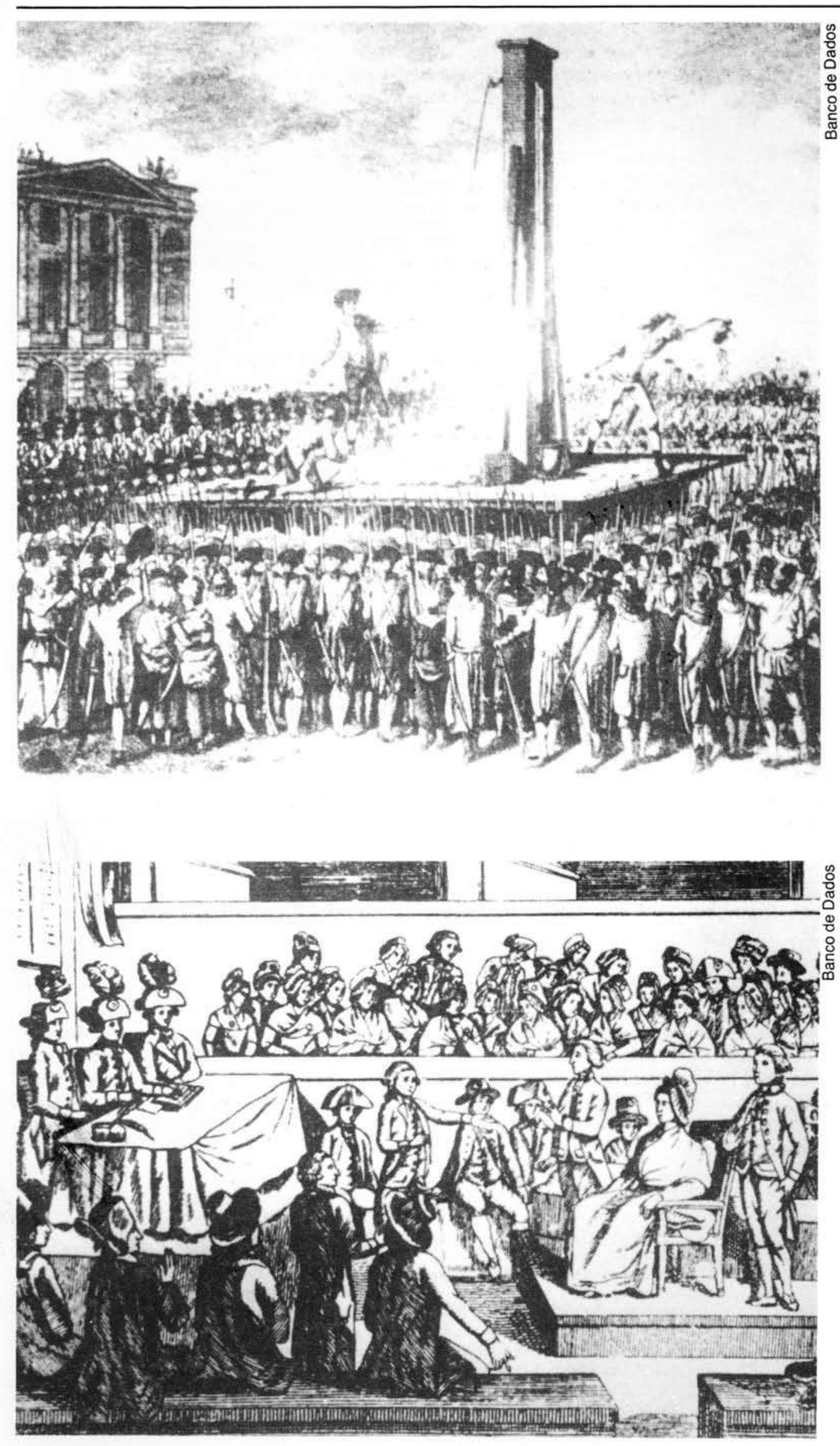

Execução de Luis XVI, em 21 de janeiro de 1793 (acima), e julgamento de Maria Antonieta, em 14 de outubro de 1793 (abaixo) 
Aumentemos nossa amostra pela observação de um texto pré-crítico de Kant. No caso dos Sonhos de um visionário, ampliados por sonhos da metafísica (1766), o objeto imediato não é a experiência religiosa senão que a capacidade de vidência. Como ela se explicaria? O filósofo parte da hipótese de o sujeito humano estar ligado aos mundos visível e invisivel, sendo daí passível de duas ordens de representações. Tais representaçōes não são entretanto entre si transitivas:

\begin{abstract}
É por conseguinte o mesmo sujeito que ao mesmo tempo pertence ao mundo visível e invisivel, mas não é a mesma pessoa pois que as representaçōes de um dos mundos, por causa de sua natureza diferente, não são idéias que acompanhem as do outro. Daí que, o que penso como espírito, não é por mim lembrado como homem e, inversamente, meu estado de homem não penetra na representação de mim mesmo como espírito (Kant, I., 1766, II, 2, 947).
\end{abstract}

A "linguagem prudente da razão" parece pois simultaneamente disposta a reconhecer a possibilidade de acesso ao mundo dos espíritos e a acentuar a desconfiança ante sua comunicação. A continuação do ensaio contudo romperá com o equilibrio das duas vias. Porque uma heterogeneidade fundamental separa as duas ordens de representação; às representações espirituais só poderemos ter acesso mediante as "representaçōes analógicas de nossos sentidos, que não são por certo o próprio conceito espiritual mas o seu símbolo" (idem, 948). O que é uma maneira polida de dizer que, sem se afirmar a fraude dos videntes e visionários, se nega, do ponto de vista do conhecimento, a legitimidade de sua informação. A conclusão é forçosa porque neles "na verdade, uma impressão espiritual efetiva está na base mas que é transformada nas silhuetas das coisas sensiveis" (ibidem, 949). A capacidade "visionária", portanto, é "uma ilusão da imaginação", "que não se manifesta imediatamente à consciência senão que através das imagens aparentadas da fantasia, que assumem a aparência das sensações" (ib., ibidem). Implicitamente, Kant já aponta para a via que desenvolverá na $1^{\text {a }}$ Crítica: para que a imaginação não seja desregrada é preciso que esteja subordinada e a serviço do entendimento. O filósofo ainda antecipa essa formulação ao dizer, em nota, que, ao despertar, o sonhante não encontra na lembrança mais do que "quimeras delirantes e aborrecidas (wilde und abgeschmackte Chimären), como o são inevitavelmente porque nele "as idéias da fantasia e as das sensações externas são intrinsecamente confundidas" (ib., 947). Em suma, o visionário "pressupõe um equilibrio alterado dos nervos", que denota "uma verdadeira doença", que se manifesta por entretecer "necessariamente a impressão espiritual" com "a fantasmagoria da imaginação" (ib., 950). Deste modo, a concessão do acesso do homem às representações espirituais termina sendo, do ponto de vista do entendimento, uma possibilidade ociosa. Os videntes são doentes dos nervos, através dos quais a imaginação mostra seu desserviço quando não subordinada ao trabalho da razão: a produção de delirantes quimeras. Assim pois será de seu controle que se poderá esperar o ultrapasse da menoridade do homern.

Nosso último testemunho nos remete por fim ao início da Revolução Francesa. Em novembro de 1793, o semanário Révolutions de Paris publica a matéria enviada pelo correspondente que cobrira a celebração, organizada na Notre Dame pela comuna e pelo departamento de Paris, da Fête de la raison. Segundo o resumo que nos apresenta H.U. Gumbrecht, para a realização do evento fora construído, sobre o cume de uma montanha artificial, um templo da filosofia, ornado pelos bustos dos grandes iluministas, no centro do qual ardia a chama da verdade. Ao som de música republicana, duas fileiras de moças, vestidas de branco, desciam da montanha. Entre elas, se encontrava "a liberdade, representada por uma bela mulher". É neste momento da descrição que o correspondente apresenta o seguinte comentário (por sua importância e raridade, transcrevo-o no original):

(...) Tout fut ordonné à propos, \& l'on doit remarquer surtout cette attention que l'on eût à employer pour représenter la liberté, une femme vivant $\&$ non point une statue. On voulut dès le premier instant déshabiller les esprits de toute espèce d'idolâtrie; on se garda bien de mettre à la place d'un saint-sacrement un simulacre inanimé de la liberté, parce que des esprits grossiers auroient pu s'y méprendre, \& à la place di dieu pain substituer un dieu pierre, il ne faut plus de superstition aux hommes: si nous renversons des cultes trompeurs, ce n'est pas pour les tromper par d'autres, pour leur présenter des objets qui puissent égarer leur imagination \& leur coeur: \& cette femme vivante, malgré tous les charmes qui l'embellissaient, ne pouvoit pas être déifiée par les ignorans, comme l'eût été une statue de pierre. - C'est donc une chose qu'il ne faut pas se lasser de dire au peuple: la liberté, la raison,I a vérité, ne sont que des êtres 
abstraits. Ce ne sont point des dieux, car à proprement parler, ce sont des parties de nous-mêmes. La liberté n'est autre chose que notre voIonté, qui a le pouvoir de se manifester \& de se réaliser. La raison n'est autre chose que cette faculté qui est en nous, de saisir la nature \& le rapport des objets; \& la vérité enfin n'est rien d'autre que la nature même. C'est le rapport réel \& primitif des choses, ce n'est donc pas une partie de notre être que nous voulons adorer, car se seroit nous adorer nousmêmes. En célébrant la fête de la liberté, de la raison, nous nous bornons à nous réjouir des avantages que nous procure cette portion de nous-mêmes qui se régénère, qui se développe en nous avec avantage. Si l'on personnifie des qualités abstraites \& métaphysiques, c'est par un langage figuré, c'est par ce que ces manières de parler jettent dans les discours \& dans les grandes assemblées plus de promptitude \& de vivacité (apud Gumbrecht, H.U., 1983, 463-4).

$\mathrm{Na}$ análise das implicações políticas da passagem, Gumbrecht destaca a oposição à dupla tendência à deificação: "À deificação de partes da natureza humana (...) e à deificação da imagem" (idem, 465). De nossa parte, assinalemos um dado mais imediato: na recepção revolucionária do legado racionalista do lluminismo, ressalta a hostilidade quanto às imagens e à sua sede. Os celebradores da festa escolhem une femme vivante pelo receio de apresentar ao povo "objetos que pudessem extraviar a sua imaginação" (Do mesmo modo, justifica-se o emprego da linguagem figurada apenas pela eficácia retórica - a presteza e a vivacidade trazida ao discurso e às assembléias - que assegura). A imaginação que, em nosso rol de atestações, estivera, pelo menos desde Bayle, ligada ao homem crédulo e à sua suscetibilidade supersticiosa, necessita ser cuidadosamente vigiada pela razão. Do contrário, a imaginação poderá exorbitar, estragando a festa da razão. Em nome pois da vocação libertária da razão será preciso, a exemplo do que fizera o dramaturgo em The Tempest, que a nobler reason de Prospero escravize a ingenuidade crente de Caliban... Prospero contudo era um representante sui generis da razão, por ser uma espécie de Fausto sem o pacto explícito com Mefisto: sua razão se desenvolvera ao contato com os livros de magia... Para os pensadores do lluminismo, essa mistura mesma era espúria e inaceitável. A nobre razão não transacionava senão com a combinação formada pelos dados dos sentidos, o entendimento e... a imaginação controlada.

Como explicaríamos a combinação entre imaginação e experiência religiosa ou parareligiosa freqüente entre os iluministas? Não seria o caso de pensar-se que o esvaziamento de sentido provocado pela Zweckrationalität (racionalidade de fim) provocava paralelamente a dúvida sobre a certeza do mundo objetivo, dúvida que era antes eliminada pela ampla estabilidade do cosmo teocêntrico? Não é bem a incerteza sobre o caráter dos conhecimentos até então legitimados que conduzira Descartes à busca de um dado que, associado ao conhecimento que se fundasse na denotatividade da aritmética, asseguraria uma segurança insofismável, mesmo que se adimitisse o poder de engano de um mauvais génie? Não era a mesma incerteza que levaria Kant, insatisfeito com o "idealismo problemático" de Descartes, à busca doutro porto de segurança, aquém e mais amplo que o cogito? Recordemos seu raciocínio. Nossa consciência de nós mesmos é uma consciência no tempo, i.e., uma consciência do mutável. Para que ela não seja apenas fluida, e daí necessariamente incerta, é preciso que seja mais do que uma mera representação. I.e., que a representação em mim corresponda à existência fora de mim de algo permanente. Noutras palavras, a consciência em mim implica a representação do que flui no tempo; para que a ela se conecte alguma certeza será preciso que corresponda ao que existe fora de mim, ocupando uma posição no espaço e dotado do caráter de permanência, i.e., sendo uma substância (cf. "Refutação do idealismo", Crítica da razão pura). Kant entretanto tem o cuidado de anotar que a mera representação de coisas exteriores não é prova suficiente de sua existência:

Do fato de que seja exigida a existência de objetos externos para a possibilidade de uma determinada consciência de nós mesmos não decorre que cada representação intuitiva de coisas externas encerra ao mesmo tempo a existência das mesmas, pois aquela representação bem pode ser o simples efeito da imaginação (denn jene kann gar wohl die bloße Wirkung der Einbildungskraft) (nos sonhos assim como na loucura); porém ela não tem lugar senão pela reprodução de percepçōes externas anteriores, as quais, (...), só são possiveis pela realidade de objetos externos (Kant, I., 1787, III, 257).

Duas notas são expressas sobre a imaginação: (a) oposta à experiência, ela não dá acesso ao externo, acesso contudo necessário para o ultrapasse do "idealismo problemático"; (b) a representação que deriva da imaginação, como seu simples efeito, reproduz "percepções externas anteriores", resultantes da "realidade de objetos externos". Ou seja, em si, a imaginação não 
poderia promover a segurança que parece particularmente obsedar o epistemólogo do mundo desencantado. Nos termos da razão pura, enquanto não-subordinada e a serviço do entendimento, a imaginação não se associa mais que ao sonho e à loucura ${ }^{(4)}$.

Em suma, nosso argumento expressa o seguinte: a experiência do desericanto do mundo torna problemático o campo da religião. Convertida para o pensador do Setecentos em questão intelectual, a religião, ao menos a que não se julga "racional", vem a ser considerada um tipo de patologia, cuja fonte se encontra no uso ilegítimo da imaginação. A "doença religiosa" é apenas uma incidência particular da psicopatologia provocada pelo imaginário. Procuramos a seguir, lançando mão da Kritik der reinen Vernunft, reiterar que 0 ataque à imaginação ultrapassa 0 próprio marco da crítica da experiência religiosa. O problema da imaginação se tornava pois particularmente sensível no século XVIII, não como decorrência direta do avanço da racionalidade científica, senão como seu efeito indireto: o desencantamento do mundo tornava incerta a fronteira entre o que era passivel de ter sentido e o que só adquiria significação por operações cognoscitivamente não-justificadas. Por isso a epistemologia de um mundo agora desencantado tinha de mostrar à imaginação o seu lugar; um lugar que, do ponto de vista do conhecimento privilegiado (o científico), haveria de ser necessariamente subalterno.

Passando agora ao segundo argumento, de ordem indutiva, procuraremos fortalecer e ampliar o raciocínio precedente.

\section{Análise de Le Rêve de D’Alembert}

O texto de Diderot (escrito em 1769, posto em circulação pela Correspondance littéraire em 1782, publicado em 1831) é bastante conhecido para que exija uma apresentação circunstanciada.

Como continuação do com que se desenvolvera no Entretien entre D'Alembert et Diderot, Le Rêve mantém o tema daquele: a reflexão sobre a origem das formas vivas, a partir do realce da sensibilidade. Le Rêve contudo se distingue pelo inusitado recurso ficcional com que é composto: a reflexão se nutre da transcrição pela Mlle. De L'Espinasse das palavras que D'Alembert teria pronunciado durante agitado sonho da noite anterior. Intrigada com o que ouvira e anotara, a companheira do geômetra convocara à sua casa o médico Théophile Bordeu para diagnosticar o estado do amigo. Bordeu era o interlocutor ideal, se não para as preocupações da senhorita, ao menos para o propósito do autor. Membro da Escola de Montpellier, Bordeu (1722-1776), responsável pelo verbete sobre a sensibilidade na Encyclopédie, era famoso por suas posiçōes vitalistas (cf. Wilson, A.M., 1972, espec. 564). É nesta condição que ele se habilita a "traduzir" e expandir o argumento que movia o sonho do geômetra. Contudo, as personagens não são apenas as três nomeadas. Já no início do sonho, apostrofando-se a si mesmo, D’Alembert apresentava seu interlocutor:

Meu amigo D'Alembert, tenha cuidado, só consideras a contigüidade onde há continuidade... (Diderot, D., 1831, 888).

Quem recorde a discussão do Entretien o identificará no ato: Diderot se insinua no sonho de D'Alembert para orientar todo o curso do diálogo. Seu argumento é fino e preciso: a vida fermenta pela passagem da contigüidade à continuidade. "Como uma gota de mercúrio se funde em uma outra gota de mercúrio, uma molécula sensivel e viva se funda em uma molécula sensivel e viva... De início havia duas gotas, depois do contato há apenas uma. Antes da assimilação havia duas moléculas, depois da assimilação só há uma... A sensibilidade torna-se comum à massa comum" (idem, ibidem). Noutras palavras, enquanto fenômeno mecânico, a contigüidade contém em potencial a continuidade orgânica e o simples se converte em complexo por efeito da própria matéria orgânica. Como nota o zeloso biógrafo de Diderot, A.M. Wilson, o filósofo, embora não dispusesse do conceito de célula e sob uma terminologia necessariamente fantasiosa, não deixava de intuí-la e precisá-la. Ao dizê-lo automaticamente, assinalamos a presença doutro interlocutor: a própria imaginação de Diderot. Sua presença se acentua a seguir: examinando a situação das abelhas agregadas (em cacho, grappe, diz o texto), Bordeu assinala que a distinção entre os estados de animais contíguos e contínuos (os pólipos) não é estável e portanto absoluta. Daí a pergunta sussurrada pela voz do interlocutor não-nomeado: não são possiveis pólipos humanos? A hipótese, mesmo que localizada na distância de Júpiter ou Saturno, não aterroriza menos a prudente De L'Espinasse. Aos poucos, entretanto, seu riso nervoso se acalma e ela se permite uma reflexão filosófica:

(4) Năo podemos aqui analisar a diferença de posiçăo que a "imaginaçăo" ocupará na $3^{\mathrm{a}}$ Crítica.
Se o homem se resolve em alguma parte em uma infinidade de homens pequeninos (d'hommes animalcules), deve-se ter menos repugnância 
O homem-pólipo contudo é apenas um passo para hipótese ainda mais ousada. Contra a idéia de um universo perenemente estável, constituído por ordens permanentes de seres, a voz oculta de Diderot formula uma explicação transformista. Sob o disfarce do sonho do amigo, é bem Diderot quem fala: "O prodígio é a vida, é a sensibilidade" (idem, 895). No mundo em que a sensibilidade domina, a fermentação é a usina produtora. Que canhestros somos em nos pensarmos membros de uma espécie sempre igual a si mesma: "Quem sabe em que instante estamos da sucessão destas gerações animais? Quem sabe se este bípede deformado, que não passa de quatro pés de altura, que ainda na vizinhança do pólo se chama um homem e que não tardaria a perder esse nome ao se deformar um pouco mais, não é a imagem de uma espécie que passa?" (idem, ibidem). Mas Diderot não se encerra a antecipar o transformismo darwinista. Sua imaginação é de uma riqueza tal que o converte no que há de mais dinâmico em seu século. Em artigo lamentavelmente hoje pouco lido, Groethuysen anotava:

\footnotetext{
O espírito no século XVIII restitui de algum modo ao pensamento sua mobilidade espontânea e cria formas em que sua individualidade poderá exprimir-se livremente. - Diderot é o filósofo dessa liberdade nova (...) (Groethuysen, B., 1913, 323).
}

Em nenhum outro lugar essa liberdade nova melhor se mostra que em sua ousadia de imaginar. Imaginação expressa sob a fórmula de hipóteses, a partir do solo das indagações científicas da época, e que não nos custa reconhecer como intuições muitas vezes certeiras porque muitas delas já confirmadas pela ciência posterior. O que então se passava com o transformismo volta a se dar com o que o século XX viria a chamar de funcionalismo. Para captá-lo, o interlocutor implicito opera com duas variáveis: a dinamicidade envolvente e sua refração pelas condições ambientais. Resumindo-nos à sua formulação mais sintética (não à mais incisiva):

Os órgãos produzem as necessidades e reciprocamente as necessidades produzem os órgãos (idem, 898).

Combinando as antecipações do transformismo e do funcionalismo, poderemos notar melhor que Diderot não se limita à condição de precursor senão que assume o papel de alguém que evita mesmo o erro dos que antecipa: seu transformismo não se confunde com o evolucionismo, pois que seu fascinio pelos monstros the impede de acatar a enganosa tranqüilidade da idéia de um progresso inevitável. O transformismo que fermenta na matéria viva não impede o teratológico, nem tampouco, como dirá em antecipação à genética, que a má-formação orgânica reapareça em descendente afastado. Por outro lado, o funcionalismo que prefigura não poderia ser acusado de imobilista em relação a um todo que tenderia a expulsar de si os elementos disfuncionais. Transformismo e função interagem em Diderot; são como que as dimensões diacrônica e sincrônica de um mesmo dinamismo. Por sua interação, o filósofo se separa dos que ressaltam as categorias de essência e de indivíduo. Não há "a essência de um ser particular", "pois que não há nenhuma qualidade de que algum ser não seja participante". Muito menos há indivíduos, no sentido forte do termo, porque "não há senão um único grande indivíduo, é o todo" (ibidem, 899). Por sua vez, dai derivảm duas conseqüências imaginativas; não poderiamos deixá-las de lado porquanto ambas vão além da acepção desencantada que o próprio lluminismo ajudava a propagar. A primeira é resultante da dinamicidade já aludida. Não há essências descontínuas, nem muito menos individualidades que se esgotem em si mesmas. A vida é uma rede de vasos comunicantes. Mas precisamos prestar atenção à própria formulação de Diderot, expressa pela voz de um D’Alembert já desperto:

\begin{abstract}
A vida (é) uma sequiência de açōes e de reaçōes. Vivo, ajo e reajo como massa... morto, ajo e reajo como moléculas... Não morro portanto? Não, sem dúvida, nesse sentido não morro, nem eu, nem quem quer que seja... Nascer, viver e passar é mudar de formas... E que importa uma forma ou outra? Cada forma tem a felicidade e a infelicidade que lhe é própria. Desde o elefante até o pulgão... desde o pulgão até à molécula sensivel e viva, origem de tudo, nâo há um ponto em toda a natureza que não sofra ou não goze (ib., 900).
\end{abstract}

A passagem é de transcrição indispensável pela dupla dicção que nela notamos. A primeira é claramente cientificista. A dinâmica envolvente da vida e da morte é explicável em termos cientificamente aceitáveis: ação e reação de uma massa enquadram a dinâmica da primeira; ação e reação de moléculas, a dinâmica da segunda. Ou seja, o sentido da vida e da morte des- 

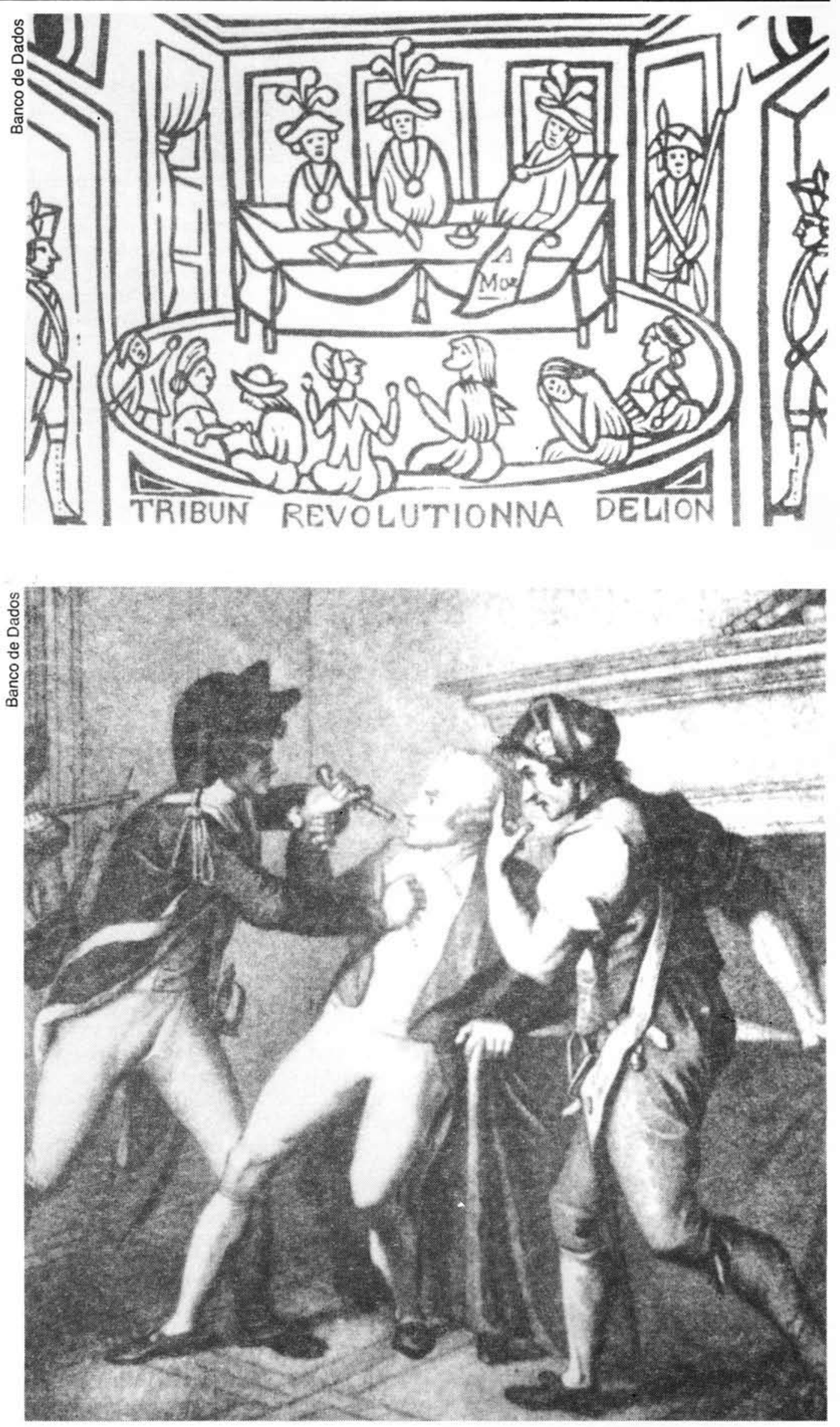

Gravura da época retratando o

Tribunal Revolucionário de Lion

(acima); tentativa de suicídio de

Robespierre ao ser preso em 1794 (abaixo) 
carta a significação de qualquer outro elemento que não fosse físico ou orgânico. A partir contudo da frase "Naître, vivre et passer...", se introduz uma nova e distinta modulação. O sofrimento e o prazer são ao mesmo tempo meios diferenciados e comuns às diversas formas do vivo. Seriam sofrimento e prazer, infelicidade e alegria explicáveis em termos mecânicos e/ou orgânicos? Mesmo porque nem o trecho transcrito, nem sua continuação tenta articular a dinâmica cientificamente explicada com a dinâmica dos afetos se evidencia a dupla modulação do pensamento. Ela poderia ser assim traduzida: Diderot ao mesmo tempo contribui para o mundo desencantado e reage contra seus limites. A validade da "tradução" é reforçada pela segunda conseqüência em que aponta a força do imaginativo. Embora a primazia da continuidade do sensível visasse a fortalecer os argumentos contrários à visão religiosa tradicional, nem por isso ela rejeita a idéia de Deus como algo que estivesse além dos limites da capacidade da razão, a exemplo do que logo diria Kant. Qual a diferença entre o ser vivo e Deus, pergunta-se o oculto interlocutor. Deus é aquele em que a continuidade se mantém em escala cósmica, ao passo que o ser vivo na existência é uma continuidade intervalar, uma continuidade cercada de contigüidades. Não se trata de uma mera versão do panteísmo espinosista. O Deus confundido com a continuidade absoluta viga (poutre) sem limites - por ser formado por matéria é um Deus mortal: "(...) Porque ele seria matéria no universo, porção do universo, sujeito a vicissitudes, envelheceria, morreria" (ib., 902).

Consideremos esse Deus mortal como a última produção do imaginário diderotiano. Desprezando o fato de que ela não teve nenhum impacto histórico, poderíamos dizer que ocupa a posição intermédia entre a saturação de sentido do cosmo religiosamente concebido, com seu Deus eterno, onipresente e onipotente, origem das criaturas e fonte da esperança humana e a Entzauberung da modernidade. Como o Deus cristão, a divindade diderotiana está além da existência mundana; como o mundo desencantado, ela é apenas matéria e sujeita à putrefação. Mortal, entretanto, ela é divina.

Chegados a este ponto, já será redundante afirmar-se que Le Rêve apresenta uma quase alucinante concentração de força do imaginário. Mas essa redundância tem seu papel: ela nos conduz a mais nitidamente perceber o contraste com que o final do diálogo dirá expressamente sobre a própria imaginação. Pois um novo regime enunciativo agora será imposto. A presença do imaginário fora inconteste e decisiva em cada passo da reflexão. Mas isso não significa que ele será legitimado quando diretamente se Ihe tematize (Por questão de espaço não abordaremos o que poderia ser tomado como o momento de passagem, representado pela reflexão em que Diderot busca, a partir das diferenças na organização diríamos fisiológica dos indivíduos, extrair uma tipologia determinística exaustiva - cf. particularmente a intervenção de Bordeu que começa por "Le grand homme...", p. 925). Concentremo-nos na passagem decisiva. Já estamos no final do diálogo quando, respondendo à curiosidade de Mille. De L'Espinasse, Bordeu contesta o que seria a imaginação:

A imaginação é a memória das formas e ciás cores. O espetáculo de uma cena, de um objeto, faz necessariamente subir o instrumento sensivel de uma certa maneira; ele sobe ou por si mesmo ou por alguma causa externa. Então freme por dentro ou ressoa por fora; registra em silêncio as impressōes que recebeu ou as manifesta por sons adequados (ib., 931).

Como a conversação que se segue não apresenta um argumento perfeitamente bemconstruido, não poderemos substituir as entradas por seu resumo. Alternam-se as réplicas de D'Alembert e de Bordeu:

\footnotetext{
- Mas seu relato exagera, omite circunstâncias, as acrescenta, desfigura o fato ou o embeleza e os instrumentos sensiveis adjacentes concebem impressōes que são bem as do instrumento que ressoa mas não a da coisa que se passou.

- É verdade, o relato é histórico ou poético.

- Mas como se introduz esta poesia ou esta mentira no relato?

- Pelas idéias que despertam umas às outras e se despertam porque sempre estiveram ligadas. Se tomaste a liberdade de comparar o animal a um cravo, permita-me comparar o relato do poeta ao canto (idem, ib.).
}

Da continuação, omitamos a nova digressão de Bordeu e substituamos a intervenção de De L'Espinasse por sua curta glosa: em princípio, cada indivíduo "vê e narra diversamente" aquilo que Ihe impressionou os olhos. Mas essa diversidade absoluta é logo retificada: cada idéia desperta outras e, de acordo com a maneira de ver ou o caráter do falante, uns se aterão "às idéias que representam o fato rigorosamente", enquanto outros aí introduzirăo "as idéias despertadas". O bom senso de De L'Espinasse conduzirá ao comentário do geômetra, com que Bordeu concordará: 
- Tens razão; o que não me impedirá de perguntar ao doutor se ele está bem persuadido de que uma forma que não se assemelhasse a nada seria engendrada na imaginação e introduzida no relato.

- Creio que não. Todo o delírio desta faculdade reduz-se ao talento desses charlatães que, de vários animais decepados, compōem um bizarro que nunca se viu na natureza (idem, 932).

$\mathrm{Na}$ abertura da citação, a identificação da imaginação com a memória parece destacar o caráter de fidelidade e passividade da primeira. Mas que significa a restrição à memória (tão só) das formas e das cores? Não o sabemos ao certo. Apenas suspeitamos que ela implica uma forma de inferioridade do produto do imaginário. Se bem que a seu propósito se possa falar em idéias, como logo o fará Mlle. De L'Espinasse, serão idéias presas ao mundo sensível, que menos o concebem que o recuperam.

No desenvolvimento imediato, Bordeu atualiza a metáfora do cravo (clavecin) interno. A imaginação é a capacidade de ressonância em nós provocada pelas impressões. Mas, se fosse apenas isso, retruca D'Alembert, como se explicaria que o relato produzido pela imaginaçāo também possa exagerar, omitir, acrescentar e desfigurar? Bordeu é forçado a admitir que sua caracterização geral não dava conta da diferença existente entre os relatos histórico e poético. Se o relato advindo da mesma fonte é passível de suscitar espécies tão diferentes será porque a marca da fidelidade não lhe é suficiente. D'Alembert já avança a diferença por sua aproximação do relato do poeta com o canto. Contudo será da responsabilidade de sua companheira a postulação mais explícita. O clavecin que em todos vibra e ressoa se conforma à diversidade que nos distingue: em uns, a ressonância segue o que de fato se deu - on s'en tient aux idées qui représentent le fait rigoureusement - noutros, ela absorve les idées reveillées (hoje diriamos as idéias que se associam). Esta segunda, a que sinteticamente chamaremos imaginação-canto, transgride a identificação com a memória; é uma memória nāo-confiável, de algum modo extraviada. No entanto, observa D'Alembert, sob a forma de pergunta, mesmo a imaginação-canto está obrigada a assemelharse a algo, i.e., a manter fidelidade ao recebido do mundo externo. Bordeu concorda e acrescenta que le délire de cette faculté consiste justamente em afastar-se deste necessário limite. Só através de seu próprio delírio, a imaginação se autonomiza da natureza.

A tematização explícita da imaginação mostra sem equivoco o controle que sobre ela exerce a razão desencantada. Não fora contudo menos nítida sua recorrência fecunda ao longo de todo o diálogo. Ambas as conclusões são relevantes. Note-se quanto à primeira: (a) podemos entender que a suspeita e até a hostilidade que o pensamento iluminista - aqui destacado enquanto primeiro formulador do pensamento da modernidade - manifesta quanto à imaginação resultava de sua freqüente associação corn a psicopatologia da experiência religiosa; com a afinidade nesta encontrada com a perduração de crendices e superstições que prejudicariam a liberação desejada do homem. Assim o advento do desencantamento implicava a desconsideração de uma faculdade, ao menos em sua manifestação além de certo limite - o da recepção fiel das impressões recebidas. Mais do que isso: o destino da imaginação não seria apenas tributário do ostracismo que a racionalidade impõe ao religioso. A imaginação é ainda atacável porque relacionada com o mito, cuja perduração não preocupava menos os racionalistas; (b) embora ultrapasse os limites desta comunicação, note-se que a imaginação não era melhor considerada dentro da cosmovisão cristã. Os motivos para tanto eram por certo outros - alguns deles já foram captados no ensaio de 1915 de Weber; mas o resultado final era idêntico: o imaginário se sujeitava ao controle; (c) não parece fortuito que a tematização do controle do imaginário surja paralelamente à crise do paradigma da modernidade e ao questionamento de sua proposta de racionalidade.

Passemos brevemente ao segundo ponto. Como se explicaria a estranha e flagrante antítese de um uso maciço da imaginação por um autor que, ao conceituá-la, procura cercá-la e restringir sua validade? Não podemos mais que sugerir um caminho: se o desencantamento se processa pelo incremento da racionalidade empírico-científica, se esta, por seu caráter de racionalidade de fim (Zweckrationalität), rejeita especificamente a imaginação-canto, pois que esta, não devolvendo a impressão recebida do externo, não contribui para o domínio da natureza, parece então não haver lugar, no mundo da Entzauberung, para a imaginação infiel, i.e., efetivamente produtora. Não obstante, Le Rêve... A explicação estaria nas contradições tantas vezes referidas de Diderot? Considerando que a hostilidade à imaginação está longe de se inaugurar com a modernidade e que nem por isso ela deixou de se manifestar, seja sob o controle religioso, seja sob o controle racionalista, parece-nos antes correto ensaiar uma explicação mais geral.

A divulgação do pensamento freudiano converteu hoje em conhecimento comum a afirmação de que o recalque da libido provoca não a sua extinção mas seu aparecimento sob a forma de perversão. Considerando-se que, como a libido, o imaginário não se confunde com uma produção cultural, pode-se indagar se o mesmo não sucede com o imaginário, quando hostilizado 
por um paradigma dominante. Por imaginaçāo perversa chamamos aquela que se manifesta no próprio interior da formação discursiva que a recalca. A demonologia não teria sido a forma perversa que o imaginário assumira sob o controle religioso? Não seriam as imaginativas explicações de cunho científico de Le Rêve sobre a origem da vida a perversão agora assumida sob o controle racional-científico? Mas o próprio paralelismo com que essas perguntas se formulam é inquietante: haveria a possibilidade de um paradigma que, dominante, não hostilizasse o imaginário? Lembrando-nos do breve hiato representado pelo romantismo de Jena e do que sucede contemporaneamente, não se poderia pensar que sua tematização só alcance interesse nos curtos instantes em que à crise de um paradigma ainda não corresponde a figura doutra dominância? Em que portanto à morte de um deus ainda não corresponde o advento de um novo?

\section{REFERÊNCIAS BIBLIOGRÁFICAS}

BLUMENBERG, H. 1979. Arbeit am Mythos. Suhrkarnp, Frankfurt a.M.

DIDEROT, D. 1831. Le Rêve de D'Alembert. In: Oeuvres. Pléiade, Paris, 1951.

DIECKMANN, H. 1974. "Reflexionen über den Begriff Raison in der Aufklärung und bei Pierre Bayle". In: Studien zur europäischen Aufklärung, W. Fink, München.

FONTENELLE, B. Le Bovier de. 1724. De l'origine des fables. In: Oeuvres, nova ed. aument., tomo III, Paris, 1743.

GROETHUYSEN, B. 1913. "La Pensée de Diderot". In: La Grande revue, n 82, Paris.

GUMBRECHT, H.U. 1983. "Die Vernunft auf der Flucht vor dem Imaginären". In: Funktionen des Fiktiven, Poetik und Hermeneutik, vol. X, W. Fink, München.

HUME, D. 1757. Natural history of religion, H.E. Root (ed.), Stanford University Press, Stanford, 1956.

KANT, I. 1766. Träume eines Geistersehers, Erläutert durch Träume der Metaphysik, W. Weischedel (ed.). In: Werkausgabe, Suhrkamp, Frankfurt a.M., 1974.

KANT, I. 1787. Kritik der reinen Vernunft (2 ed.), W. Weischedel (ed.). In: Werkausgabe, op. cit.

MANUEL. F. 1959. The Eighteenth century confronts the gods, Harvard University Press, Cambridge, Mass.

SCIASCIA, L. 1974. "Luciano e le fedi", pref. a Luciano, I Dialoghi, Einaudi, Torino.

WEBER, M. 1915. "Zwischenbetrachtung", trad. de H.H. Gerth e C.W. Mills, sob o título de "Religious rejection of the world and their directions". In: From Max Weber: essays in sociology, Oxford University Press, New York, 1958.

WILSON, A.M. 1972. Diderot, Oxford University Press, New York. 